\title{
Implementasi Kegiatan Ektstrakurikuler PAI (Ikhrohist) untuk Pembinaan Akhlak
}

\author{
Sudiran \\ Pendidikan Agama Islam, Pasca sarjana, Universitas Islam Negeri Alauddin Makassar \\ Email: sudirankarim@gmail.com
}

\begin{abstract}
This researh is about the implementation of extracurricular activities (ikrohist) for guide students'attitude in SMK Penerbangan Techno Terapan Makassar. This research method is a qualitative research using of normative theology, pedagogic, physicologic, and sociologic. The research instruments used interview, observation, and documentation. Informant consisted of principal, refresentative of the school, and teachers. Data collection was done by observation, interview and documentation techniques. Data analysis by means of data reduction, data presentation, conclusion and data verification. The result of this research, there are: 1) Students' attitudes in SMK Penerbangan Techno Terapan Makassar, after joining the extracurricular activities showed good attitudes. 2) Students' Attitudes in SMK Penerbangan Techno Terapan Makassar based on the observation and interview that give awardness, discipline, extracurricular activities (Ikrohist) in SMK Penerbangan Techno Terapan Makassar consisted of three parts, they are dayly/weekly activities, monthly activities and annual activities.
\end{abstract}

Keywords: Religious Extracurricular, Ikrohist activities, Moral

\section{Abstrak}

Penelitian ini mengenai Implementasi Kegiatan ekstrakurikuler (PAI) Ikatan Kerohanian Islam Techno untuk Pembinaan Akhlak Peserta Didik di SMK Penerbangan Techno Terapan Makassar'. Penelitian ini adalah penelitian kualitatif dengan menggunakan pendekatan teologis normatif, pendekatan pedagogis, pendekatan psikologis, dan pendekatan sosiologis. Informan terdiri atas kepala sekolah, wakil kepala sekolah, staff, pembina, guru PAI dan Peserta didik. Pengumpulan data digunakan dengan teknik observasi, wawancara dan dokumentasi. Analisis data menggunakan cara reduksi data, penyajian data, kesimpulan dan verifikasi data. Dengan hasil penelitian yang diperoleh yaitu: 1) akhlak peserta didik di SMK Penerbangan Techno Terapan Makassar, setelah mengikuti kegiatan ekstrakurikuler menunjukkan akhlak yang terpuji. 2). Akhlak peserta didik di SMK Penerbangan Techno Terapan Makassar berdasarkan dari hasil observasi dan interview setelah peserta didik mengikuti kegiatan ekstrakurikuler PAI (ikrohist) memberikan kesadaran, disiplin, kegiatan ekstrakurikuler ikrohist di SMK Penerbangan Techno Terapan Makassar terdiri atas tiga bagian, yaitu Kegiatan harian/mingguan, Kegiatan bulanan., Kegiatan tahunan 


\section{Pendahuluan}

Latar belakang masalah pada tulisan ini adalah Peserta didik pada Sekolah Menengah Kejuruan Penerbangan Techno Terapan Makassar termasuk kategori heterogen dengan keberagaman budaya, suku dan latar belakang yang berbeda-beda seperti ekonomi, sosial sehingga dapat mempengaruhi kondisi psikologis peserta didik. Menyadari kondisi tersebut maka perlu penanaman akhlak pada setiap peserta didik dengan keberagaman dapat terkontrol dan terkoordinir dengan baik yang dapat menjadi kelebihan dan tidak menjadi suatu kekurangan.

Implementasi kegiatan ektrakurikuler pendidikan agama Islam (ikrohist) diharapkan mampu mengembangkan kepribadian peserta didik agar dapat bersikap luhur dan mulia. Pendidikan merupakan proses membantu manusia untuk mengembangkan dirinya dan meningkatkan harkat serta martabat manusia, sehingga mampu menghadapi setiap perubahan yang terjadi menuju arah yang lebih baik.

Adapun rumusan masalah dalam tulisan ini yaitu: 1) Bagaimana gambaran akhlak peserta didik di SMK Penerbangan Techno Terapan Makassar. 2) Bagaimana bentuk kegiatan ekstrakurikuler pendidikan agama Islam di SMK Penerbangan Techno Terapan Makassar. 3) Bagaimana hasil kegiatan ekstrakurikuler pendidikan agama Islam untuk pembinaan akhlak peserta didik di SMK Penerbangan Techno Terapan Makassar.

Tujuan penelitian ini adalah 1) untuk mengetahui gambaran akhlak peserta didik di SMK Penerbangan Techno Terapan Makassar. 2) Untuk mengetahui bentuk kegiatan ekstrakurikuler pendidikan agama Islam di SMK Penerbangan Techno Terapan Makassar. 3) Untuk mengetahui hasil kegiatan ekstrakurikuler pendidikan agama Islam untuk pembinaan akhlak peserta didik di SMK Penerbangan Techno Terapan Makassar.

Berdasarkan hasil penelitian diatas telah ada penelitian yang hampir sama dilakukan yaitu oleh peneliti sebelumnya namun pada dasarnya memiliki perbedaan yang signifikan yaitu penelitian terdahulu hanya meneliti tentang pembinaan akhlak siswa melalui metode mengajar guru pendidikan agama Islam. namun belum mengkaji pembinaan akhlak peserta didik pada pelaksanaan kegiatan ektrakurikuler PAI di sekolah SMK yang kami teliti.

Kegiatan ekstrakurikuler adalah suatu upaya kegiatan pendidikan diluar mata pelajaran untuk membantu pengembangan peserta didik sesuai dengan bakat dan minat, kebutuhan serta potensi melalui kegiatan yang secara khusus di selenggarakan oleh pendidik atau tenaga kependidikan yang berkemampuan dan berkewenangan disekolah. ${ }^{1}$

${ }^{1}$ Departemen Pendidikan Nasional, Panduan Lengkap KTSP, (Yogyakarta: Mitra Pustaka, 2007), h. 213. 
Kegiatan ekstrakurikuler pendidikan agama Islam merupakan upaya pemantapan dan pengayaan nilai-nilai dan norma serta pengembangan kepribadian, bakat dan minat peserta didik pada pendidikan agama Islam yang dilaksanakan di luar jam intrakurikuler dalam bentuk tatap muka atau non tatap muka, dengan tujuan untuk memperdalam, memperluas wawasan dan pengetahuan peserta didik tentang pendidikan agama Islam dan menjadikan agama sebagai landasan akhlak mulia dalam kehidupan pribadi, berkeluarga, bermasyarakat, berbangsa dan bernegara serta membangun sikap mental peserta didik untuk bersikap dan berprilaku jujur, amanah, disiplin, bekerja keras, mandiri, percaya diri, kooperatif, ikhlas dan bertanggung jawab.

Implementasi kegiatan ekstrakurikuler yang penulis maksud dalam penelitian ini adalah pelaksanaan kegiatan-kegiatan yang dilaksanakan oleh ikhrohist (ikatan kerohanian Islam Techno) dalam membentuk kepribadian peserta didik dan atau untuk membina akhlak peserta didik di luar kurikulum atau tidak dilaksanakan melalui proses belajar mengajar atau memberikan pengetahuan pengembangan bakat dan keterampilan yang pada kelas regular memiliki jam pelajaran yang sangat minim khususnya pendidikan agama Islam.

Pembinaan akhlak di SMK Penerbangan Techno Terapan melalui Ekstrakurikuler sangat dibutuhkan bukan hanya dalam kehidupan sehari-hari namun dalam dunia kerja yang nantinya akan mereka terapkan ketika selesai mengenyam pendidikan di SMK Penerbangan dengan pernyataan akhlak mulia akan memberikan ketenangan dalam bermasyarakat, berbangsa dan bernegara.

\section{Metode Penelitian}

Jenis penelitian ini adalah kualitatif, yaitu prosedur penelitian yang menghasilkan data deskriptif berupa kata-kata yang tertulis atau lisan dari orang-orang dan perilaku yang diamati, ${ }^{2}$ Desain penelitian ini merupakan kualitatif deskriptif, untuk menganalisis dan menggambarkan penelitian secara objektif dan mendetail untuk mendapatkan hasil yang akurat.

Populasi adalah keseluruhan objek penelitian, apakah berupa manusia, gejala-gejala, benda-benda, pola sikap, tingkah laku atau segala sesuatu yang menjadi objek penelitian dan populasi secara keseluruhan 35 orang. Populasi yang dijadikan sampel ini adalah 35 orang dengan menggunakan sampel acak. Hal ini dilakukan untuk mendapatkan data yang akurat dalam penelitian.

Peneliti menentukan fokus pertanyaan dari sumber data sebagai berikut:

${ }^{2}$ S. Margono, Metodologi Penelitian Pendidikan, (Jakarta: Rineka Cipta, 1997), h. 36. 
1. Bagaimanakah bentuk pelaksanaan kegiatan ekstrakurikuler Pendidikan Agama Islam di SMK Penerbangan Techno Terapan Makassar?

2. Bagaimanakah gambaran akhlak, mental/prilaku peserta didik khususnya yang beragama Islam di SMK Penerbangan Techno Terapan Makassar?

3. Upaya-upaya apa sajakah dilakukan dalam proses pembinaan akhlak, mental/prilaku peserta didik di SMK Penerbangan Techno Terapan Makassar?

Form dokumentasi peneliti gunakan untuk memperoleh data dokumen implementasi kegiatan ekstrakurikuler PAI, profil sekolah, data jumlah pendidik, dan jumlah tenaga kependidikan serta jumlah peserta didik di SMK Penerbangan Techno Terapan Makassar. Data tersebut sangat membantu peneliti dalam menggabungkan data-data yang diperoleh melalui observasi, interview dan dokumentasi.

Metode yang penulis gunakan dalam mengumpulkan data melalui:

a) Observasi yaitu proses yang dilaksanakan peneliti dengan cara mengamati secara langsung objek penelitian dengan jarak dekat. Sugiono dan Nasution, menyatakan bahwa observasi adalah dasar semua ilmu pengetahuan. Para ilmuwan hanya biasa bekerja berdasarkan data, yaitu fakta mengenai dunia kenyataan yang diperoleh melalui observasi. ${ }^{3}$

b) Wawancara (In-Depth Interview), adalah salah satu cara untuk mengumpulkan data pada suatu penelitian, Bentuk pertanyaan yang digunakan pada wawancara ini adalah pertanyaan yang tidak terstruktur karena ingin memberi kebebasan kepada informan untuk menjawab pertanyaan yang diajukan oleh peneliti.

c) Dokumentasi, yakni penulis menelusuri data yang relevan dengan objek penelitian dalam bentuk arsip-arsip atau catatan sebagai sumber data ${ }^{4}$. Dokumen adalah sesuatu yang tertulis atau tercetak yang dapat dipakai sebagai alat bukti atau keterangan, seperti mengambil dokumen resmi, baik dalam bentuk statistik, maupun dokumen narasi yang dapat menunjang penelitian ini.

Teknik analisis data yang digunakan oleh penulis adalah teknik triangulasi dengan maksud memanfaatkan sesuatu yang lain di luar data yang ada untuk kepentingan pengujian keabsahan data atau sebagai bahan

\footnotetext{
h. 345 .

${ }^{3}$ Sugiono, Metode Penelitian Pendidikan; Pendekatan Kuantitatif, Kualitatif, dan $R \& D$,

${ }^{4}$ Sukardi, Metodologi Pendidikan Kompetensi dan Prakteknya. (cet. V; Jakarta: Bumi Aksara, 2008), h. 81
} 
perbandingan terhadap data yang ada. Triangulasi dilakukan dan digunakan untuk mengecek keabsahan data yang terdiri dari sumber, metode dan waktu. ${ }^{5}$

\section{Gambaran akhlak peserta didik}

Interaksi peserta didik dengan dunia luar jauh lebih banyak jika dibandingkan dengan interaksi di sekolah, sehingga sangat tidak mungkin dalam waktu hanya 2 (dua) jam di sekolah untuk merubah peserta didik memiliki akhlak yang tidak terpuji menjadi berperilaku atau memiliki akhlak yang terpuji dengan cepat. Untuk itu alokasi waktu sangat berpengaruh terhadap penanaman, pembentukan akhlak terpuji pada peserta didik agar peserta didik bisa mengimplementasikannya dalam kehidupan sehari-hari khususnya di sekolah maupun pada umumnya di luar sekolah.

Peserta didik yang majemuk dengan suku budaya yang berbeda-beda serta asal yang berbeda pula menjadikan SMK penerbangan Techno Terapan Makassar memiliki peserta didik multi dimensi akhlak. dari sifat yang terpuji sampai sifat buruk.

Kendala yang sering ditemui dalam proses pembelajaran adalah masalah peserta didik dan masalah alokasi waktu, karena kedua hal tersebut merupakan dua komponen yang saling berkaitan. Dari segi peserta didik sendiri, dapat ditemukan bahwa perilaku peserta didik sudah terbentuk sebelum mereka memasuki dunia sekolah, baik itu perilaku yang buruk maupun perilaku yang baik, sebab adanya interaksi antara peserta didik dengan lingkungan hidupnya, baik itu lingkungan keluarga, lingkungan masyarakat maupun lingkungan bermainnya.

Untuk itu alokasi waktu sangat berpengaruh terhadap penanaman, pembentukan akhlak terpuji pada peserta didik agar peserta didik bisa mengimplementasikannya dalam kehidupan sehari-hari khususnya di sekolah maupun pada umumnya di luar sekolah.

Hasil observasi yang peneliti lakukan juga memperlihatkan adanya gambaran akhlak peserta didik selama berada di lingkungan SMK Penerbangan Techno Terapan Makassar. Diantaranya masih ditemukannya beberapa peserta didik yang tidak memberikan hormat pada saat berjumpa dengan seniornya, peserta didik terkadang memanggil nama peserta didik yang lainnya dengan panggilan yang kurang baik, beberapa peserta didik sering duduk diatas meja.

hasil interview dengan salah satu warga yang tinggal di sekitar lingkungan sekolah menyatakan bahwa Pada awal peserta didik SMK Penerbangan Techno Terapan Makassar mencerminkan akhlak/perilaku yang kurang baik, seperti peserta didik yang sering terlambat sekolah, sering

${ }^{5}$ Sanafiah Faisal, Metodologi Penelitian Sosial (Cet.I; Jakarta: Erlangga, 2001), h. 33. 
mangkir diwarung kami sambil merokok, sering berteriak-teriak dengan katakata yang kurang sopan kepada sesama rekannya. Akan tetapi sekarang sangat nampak berbeda, dalam artian peserta didik SMK Penerbangan Techno Terapan Makassar sudah tidak terlihat melakukan hal yang tidak bermanfaat. ${ }^{6}$

Berdasarkan dari hasil interview menunjukkan bahwa akhlak peserta didik SMK Penerbangan Techno Terapan Makassar sebelum aktif pada kegiatan ekstrakurikuler, tergolong tidak sesuai dengan harapan yang diinginkan oleh semua pihak baik dari pihak sekolah, pemerintah, masyarakat dan orang tua.

Adapun upaya-upaya yang harus dilakukan diantaranya pembinaan akhlak peserta didik yaitu dengan mengaktifkan rangkaian kegiatan ekstrakurikuler Pendidikan Agama Islam, sebab pelaksanaan kegiatan ekstrakurikuler selain menambah wawasan dan pengetahuan peserta didik juga membina akhlak peserta didik itu sendiri. Pembina ekstrakurikuler Pendidikan Agama Islam di SMK Penerbangan Techno Terapan Makassar wajib melaksanakan pembinaan akhlak bagi peserta didik sehingga perlu dilakukan dalam berbagai cara. Kondisi peserta didik yang beragama Islam yang telah menunjukkan perilaku kearah religious culture akan semakin tampak dengan berbagai upaya yang dilakukan oleh pembina ekstrakurikuler Pendidikan Agama Islam.

\section{Bentuk- Bentuk kegiatan}

Berbagai macam bentuk kegiatan yang telah dilakukan dan diupayakan oleh pihak sekolah guna meningkatkan kualitas kemampuan siswa baik kognitif, psikomotorik maupun afektif. Dalam pelaksanaan kegiatan ekstrakurikuler Pendidikan Agama Islam, peserta didik SMK Penerbangan Techno Terapan Makassar, dalam hal ini dibimbing, dibina oleh pendidik Pendidikan Agama Islam dan juga oleh pembina-pembina lain yang telah ditetapkan oleh pihak sekolah dan yang sengaja didatangkan dari luar sekolah.

Bentuk-bentuk kegiatan ekstrakurikuler itu dikembangkan dengan mempertimbangkan tingkat pemahaman dan kemampuan peserta didik, serta tuntutan-tuntutan lokal madrasah atau sekolah kejuruan berbeda, sehingga melalui kegiatan yang diikutinya, peserta didik mampu belajar untuk memecahkan masalah-masalah yang berkembang di lingkungannya, dengan tetap tidak melupakan masalah-masalah global seperti adanya tuntutan

\footnotetext{
${ }^{6}$ Abd.Rahman, Warga Pemilik Rumah Kos dan Warung disekitar Sanrangan II, Interviewoleh penulis di Rumahnya., 19 Agustus 2018.
} 
perkembangan ilmu pengetahuan dan technologi (IPTEK)/ dunia milaniar, yang tentu saja harus diketahui oleh peserta didik. ${ }^{7}$

Setiap tahun atau ketika pergantian kepengurusan ekstrakurikuler keagamaan, melaksanakan perekrutan yang dari tahun ke tahun semakin meningkat dan dianggap berhasil, keberhasilan tersebut dinilai melalui Laporan Pertanggung Jawaban (LPJ) kependidikan diakhir jabatannya.

Pelaksanaan program-program kegiatan ekstrakurikuler keagamaan SMK Penerbangan Techno Terapan Makassar dapat digambarkan sebagai berikut:

a. Kegiatan Harian dan Mingguan

1) Shalat Dzuhur

Dalam meningkatkan kualitas pendidikan agama Islam di SMK Penerbangan Techno Terapan Makassar, maka pembiasaan terhadap peserta didik untuk shalat dzuhur secara berjema'ah dalam kehidupan sehari-hari. Selain shalat dzuhur berjema'ah, pembiasaan dilakukan dengan cara membacakan risalah hadist beserta artinya, setelah ba'da shalat dzuhur dan ba'da shalat ashar yang dilakukan oleh peserta didik secara bergantian dengan waktu tiga puluh menit.

2) Yasinan

Kegiatan ini dilakukan setiap hari kamis malam ba'da shalat maghrib sampai ba'da shalat isa di masjid SMK Penerbangan Techno Terapan Makassar.

3) Tadarus Al-Qur'an

Kegiatan ini dilakukan setiap hari jum'at pagi, setelah melaksanakan apel pagi, dan diikuti oleh semua peserta didik khususnya yang beragama Islam, selama kurang lebih tiga puluh menit.Tujuannya adalah agar peserta didik dapat memperlancar baca'an-baca'an al-Qur'an. ${ }^{8}$

3) Shalat Jum'at Berjemaah.

Kegiatan shalat jum'at berjemaah, dilaksanakan setiap hari jum'at di masjid SMK Penerbangan Techno Terapan Makassar.Kegiatan ini diwajibkan bagi semua peserta didik laki-laki khususnya yang beragama Islam.

4) Seni Membaca al-Qur'an

Kegiatan seni membaca al-Qur'an dilakukan setiap hari ba'da jum'at sampai dengan jam 15.00. Kegiatan ini mengarahkan peserta didik untuk selalu mencintai seni membaca al-Qur'an yang bersifat Islami, serta sebagai upaya sekolah dalam menjaga dan menghindarkan peserta didik dari kebudayaan asing yang bertentangan dengan nilai-nilai Islam.

\footnotetext{
${ }^{7}$ Abdul Muis., Wakasek Kesiswaan Pendidik SMK Penerbangan Techno Terapan Makassar, Interview oleh penulis di Ruang Wakasek, 8 Agustus 2018.

${ }^{8}$ St. Rosmiati, Pendidik PAI SMK Penerbangan Techno Terapan Makasar, Interview oleh penulis di Ruang Pendidik, 15 Agustus 2018
} 
b. Kegiatan Bulanan

1) Infaq

Dalam meningkatkan mutu pendidikan agama Islam di SMK Penerbangan Techno Terapan Makassar, program rutin bulanan yang selalu dilaksanakan adalah infaq.

2) Kajian Islami

Kajian Islami dilakukan dua kali setiap bulan bertujuan untuk menambah wawasan dan pengetahuan peserta didik tentang keislaman. Kajian Islami diikuti oleh pengurus dan anggota ikrohist yang dipimpin oleh para murabbi yang belajar di Universitas dan perguruan tinggi dengan mengadakan kerja sama dan secara sukarela memberikan pemahaman tentang keislaman.

c. Kegiatan Tahunan

1) Peringatan Hari Besar Islam

Adapun waktu pelaksanaan sesuai dengan waktu yang telah ditentukan dalam kalender nasional, yaitu:

a) Peringatan Isra' Mi'raj

b) Peringatan tahun baru Hijriah

c) Peringatan Maulid Nabi Muhammad saw.

2) Pesantren Kilat

Dalam memanfaatkan waktu libur pada bulan suci Ramadan, SMK Penerbangan Techno Terapan Makassar mengadakan kegiatan pesantren kilat selama tujuh hari dan ditutup dengan mengadakan buka puasa bersama. Kegiatan ini dimaksudkan agar peserta didik semangat dalam melaksanakan ibadah dalam kehidupan sehari-hari. Selain itu peserta didik dapat menimba ilmu pengetahuan praktis yang tidak diajarkan dalam kurikulum 2013. ${ }^{9}$

Kegiatan ekstrakurikuler yang dilaksanakan memiliki tujuan yaitu untuk menumbuhkan akhlak peserta didik serta dapat mengambil hikmah dari kegiatan tersebut. Setiap program kegiatan diusulkan oleh pembina ekstrakurikuler kepada wakil kepala sekolah urusan kesiswaan, setelah usulan tersebut disetujui, maka program kegiatan dilaksanakan sesuai dengan rencana yang telah ditentukan.

\section{Dampak Kegiatan}

Hasil pendidikan dipandang bermutu bila melahirkan peserta didik yang unggul dibidang akademik dan berprestasi pada kegiatan ekstrakurikuler serta dinyatakan lulus untuk satu jenjang pendidikan atau menyelesaikan program pembelajaran tertentu. Unggul dinyatakan dibidang

${ }^{9}$ St. Rosmiati, Pendidik PAI SMK Penerbangan Techno Terapan Makassar, Interview oleh penulis di Ruang Pendidik, 15 Agustus 2018 
akademik sesuai dengan nilai capaian oleh peserta didik dan dinyatakan unggul dalam ekstrakurikuler sesuai dengan jenis keterampilan yang diperoleh peserta didik selama mengikuti program ekstrakurikuler.

Dampak dari kegiatan ekstrakurikuler pendidikan agama Islam untuk pembinaan akhlak bagi peserta didik di SMK Penerbangan Techno Terapan Makassar antara lain:

a. Antusias peserta didik dalam mengikuti kegiatan ekstrakurikuler pendidikan agama Islam cukup baik karena peserta didik mengikuti kegiatan ekstrakurikuler pendidikan agama Islam atas kemauan sendiri.

b. Peserta Didik Lebih Disiplin dalam Melakukan Shalat Berjamaah. peserta didik telah mampu melaksanakan shalat berjamaah dengan baik dengan penuh kesadaran.

c. Menumbuhkan Rasa Solidaritas dan Kepekaan Sosial Antar Sesama.

Selain kedisiplinan yang merupakan tujuan diadakannya kegiatan ekstrakurikuler, rasa solidaritas dan kepekaan sosial antar sesama yang mengalami kesusahan dan kesulitan merupakan tujuan selanjutnya dari kegiatan ekstrakurikuler. Hal ini terlihat dari hasil observasi peneliti, peserta didik menyisihkan sebagian uang sakunya ketika salah satu warga sekolah mengalami musibah, dan tanpa dikoordinir peserta didik memberikan kontribusinya untuk mengurangi beban sesama.

Dalam teori yang disebutkan sebelumnya bahwa dalam pembinaan akhlak peserta didik pada kegiatan ekstrakurikiuler pendidikan agama Islam maka semua cara, kondisi dan peristiwa dalam kegiatan ekstrakurikuler selalu diarahkan pada kesadaran nilai-nilai universal agama sekaligus upaya pemeliharaan fitrah beragama. Oleh karena itu, pada beberapa sekolah dan madrasah, program ekstrakurikuler khususnya ekstrakurikuler keagamaan dikembangkan secara integral baik dalam penataan fisik maupun psikis.

Kegiatan ekstrakurikuler pendidikan agama Islam di SMK Penerbangan Techno Terapan Makassar dapat meningkatkan pemahaman peserta didik tentang nilai-nilai ajaran agama serta pembinaan akhlak sebagai bekal hidup dan menjadi manusia yang beriman dan bertakwa sebagaimana tujuan pendidikan nasional.

\section{Simpulan}

\section{Penutup}

Berdasarkan uraian yang telah dikemukakan sebelumnya maka penulis menyimpulkan sebagai berikut: (1) Peserta didik pada SMK Penerbangan Techno Terapan Makassar yang memiliki latar belakang sosial, ekonomi dan daerah yang variatif sehingga keberagaman yang ada diantara peserta didik dapat menjadi wadah kebersamaan dengan mengikuti kegiatan ikrohist sebagai bentuk pembinaan akhlak terhadap perserta didik. (2) Bentuk 
pelaksanaan kegiatan ekstrakurikuler pendidikan agama Islam (Kegiatan Ikhrohist) di SMK Penerbangan Techno Terapan Makassar terbagi atas 3 bagian, yaitu kegiatan harian/mingguan, yang terdiri atas Shalat Dzuhur, Yasinan, Tadarus Al-Qur'an, Jum'at Bersih/BaktiSosial, Shalat Jum'at Berjama'ah, Seni Membaca al-Qur'an. Adapun kegiatan bulanan meliputi: infaq dan kajian Islami. Sedangkan kegiatan tahunan meliputi: peringatan hari-hari besar Islam, pesantren kilat dan ditutup dengan buka puasa bersama. (3) Hasil kegiatan ekstrakurikuler pendidikan agama Islam (Kegiatan Ikrohist) untuk pembinaan akhlak peserta didik SMK Penerbangan Techno Terapan Makassar, memberikan pengaruh yang positif. Peserta didik yang sering melakukan pelanggaran merasa ada perubahan positif setelah mengikuti kegiatan ekstrakurikuler pendidikan agama Islam (Kegiatan Ikrohist) diaktifkan. Adapun pengaruh dari kegiatan ekstrakurikuler pendidikan agama Islam untuk pembinaan akhlak peserta didik diantaranya adalah antusiasnya peserta didik dalam mengikuti berbagai kegiatan ekstrakurikuler pendidikan agama Islam (Kegiatan Ikrohist) cukup baik sebab peserta didik mengikuti kegiatan atas kemauannya sendiri, peserta didik lebih disiplin dalam memanfaatkan waktunya sedemikian rupa, disiplin dalam melaksanakan shalat fardhu lima waktu secara berjema'ah, serta tumbuhnya kepekaan sosial terhadap lingkungan dan sesama manusia.

\section{Saran}

Berdasarkan hasil temuan dan kesimpulan yang telah dipaparkan, implikasi dari penelitian ini adalah sebagai berikut: (1) Hendaknya kepada pihak sekolah untuk menjadikan akhlak sebagai orientasi utama dan pertama didalam penilaian dengan diimbangi oleh kapasitas intelektual peserta didik khususnya di SMK Penerbangan Techno Terapan Makassar. (2) Kegiatan ekstrakurikuler pendidikan agama Islam, khususnya kegiatan Ikrohist (Ikatan Kerohanian Islam Techno), tetap dipertahankan dan di tingkatkan lagi bagi pihak sekolah. (3) Melihat adanya pengaruh yang positif dari kegiatan ekstrakurikuler pendidikan agama Islam, khususnya kegiatan Ikrohist (Ikatan Kerohanian Islam Techno) di SMK Penerbangan Terapan Makassar, tentunya menjadi acuan lebih mengarah pada pengembangan pada kegiatan tersebut.

\section{Daftar Pustaka}

Abdurrahman, Pengelolaan Pengajaran, Ujung Pandang: Bintang Selatan, 1991.

Abidin, Mas'oed. Hidupkan Energi Ruhani: Akhlak Remaja Hari Ini dan Prospeknya di Masa Depan dalam 
http://buyamasoedabidin.wordpress. com/2009/05/24/pembinaan akhlak remaja/ (20Maret 2018).

Abrasy, Prof Dr. Mohd' Athiyah.Al-Tarbiyah Al-Islamiyah, diterjemahkan oleh. Prof. H. Bistami A. Gani, Dasar-dasarPokok Pendidikan Islam,Cet. I; Jakarta: Bulan Bintang, 1970.

Ahmadi, Abu dan Munawar Sholeh. Psikologi Perkembangan, Jakarta: Rineka Cipta, 2005.

Alang, Sattu. Kesehatan Mental dan Terapi Islam, Cet. II, Makassar: CV. Berkah Utami, 2005.

Ali, Muhammad Daud. Pendidikan Agama Islam, Ed. I, Jakarta: Raja Grafindo Persada, 2006.

-------, Penelitian Kependidikan Prosedurdan Strategi, Cet. III, Bandung: Angkasa, 1985.

al-Jumbati, Ali. dkk, Perbandingan Pendidikan Islam, terjemahan H. M. Arifin, Jakarta: Rineka Cipta, 2002.

an-Nahlawi, Abdurrahman. Pendidikan Islam di Rumah, Sekolah, danMasyarakat, Jakarta: GemaInsani, 1995.

Apriyanto.Pembelajaran Ekstrakurikuler PAI; Suatu Pengantar, tanggal 22 Juni 2009

dalam

http://april76.wordpress.com/2009/06/22/pembelajaran ekstrakurikuler-pai-suatupengantar, (20 Maret 2018).

AR, Zahruddin. Pengantar Ilmu Akhlak,Cet. I, Jakarta: PT. Raja Grafindo Persada, 2004.

Ardani, Moh. Akhlak Tasawuf, Cet. II, Jakarta: PT. MitraCahaya Utama, 2005.

Arikunto, Suharsimi. ProsedurPenelitian; Suatu Pendekatan Praktik, Edisi Revisi, Cet. VIII, Jakarta: Rineka Cipta, 1992.

------, Dasar-dasar Evaluasi Pendidikan, Yogyakarta: Bumi Aksara, 1993.

B, Chaeruddin. Metode Pengajaran Agama Islam Luar Sekolah, Yogyakarta: Lanarka, 2009.

Budiningsih, Asri. Pembelajaran Moral, Berpijak Pada Karakteristik Siswadan Budayanya, Jakarta: Rineka Cipta, 2004.

Burrep, Percy E. Modern High School Administration, New York: Harper \& Brothers Publisher, 1962.

C. Rumpak, dkk. Kamus Besar Bahasa Indonesia, Jakarta: Balai Pustaka, 2003.

Darajat, Zakiyah. Peran Agama dalam Kesehatan Mental, Jakarta: Gunung Agung, 1995.

------, Dasar-Dasar Agama Islam, Cet. X. Jakarta: Bulan Bintang, 1996.

------, Pendidikan Agama dan Akhlak bagi Anak dan Remaja, Cet. I. Jakarta: Logos Wacana Ilmu, 2001. 
-------, Pengajaran Agama Islam, Cet. II. Jakarta: Bumi Aksara, 2001.

------, Kesehatan Mental. Jakarta: Haji Masagung, 1990.

David, Keith. Human Ralation Work TheDinamic Organization Behavior, New York: Mc. Graw Hill, 1985

Djatnika, Rahmat. Sistem Etika Islam; Akhlak Mulia, Cet. I. Surabaya: Pustaka, 1987.

Departemen Agama RI. Al-Qur'an dan Terjemahan. Bandung: CV. Jumanatul Ali-Art (J-ART), 2005

---------, Peraturan Direktorat Jenderal Pendidikan Islam Departemen Agama RI Nomor Dj.I/12 A tahun 2009 tentang Pelaksanaan Ekstrakurikuler Pendidikan Agama Islam (PAI) padasekolah, 2009

DepartemenPendidikan Nasional, Panduan Lengkap KTSP, Yogyakarta: Mitra Pustaka 2007.

Departemen Pendidikan dan Kebudayaan, Pedoman Pelaksanaan Ekstrakurikuler, Kurikulum SMK, Jakarta: Depdikbud, 1984.

Echols John M.dan Hasan Shadily, Kamus Inggris Indonesia, Jakarta: Gramedia, 1989.

Hadari, Nawawidan Martini Hadari, Instrumen Penelitian Bidang Sosial, Cet. II; Yogyakarta: Gajah MadaUniveristy Press, 1995.

Hasan, M. Ali. Tuntunan Akhlak, Cet. III; Jakarta: BulanBintang, 1983.

Ilyas,Yunahar. Kuliah Akhlak, Cet. IV; Yogyakarta: PustakaPelajar, 2001.

Jaelani, A. F. Penyucian Jiwa (Tazkiya al-Nafs) dan Kesehatan Mental, Jakarta: Amzah, 2000.

Kementerian Agama RI, al-Qur'an The Great Miracle, Solo: PT. Tiga Serangkai Pustaka Mandiri, 2013.

Kementerian Agama RI, al-Qur'an The Great Miracle, Solo: PT. Tiga Serangkai Pustaka Mandiri, 2013.

Perum Penerbitan dan Percetakan, Kamus Besar Bahasa Indonesia, Jakarta: Balai Pustaka, 1998.

Pidarte, Made. Pemikiran tentang Supervisi Pendidikan, Malang: Sarana Press, 1986.

Ranupandojo, Heidjrahman dan Suad Husnan, Manajemen Personalia, Yogyakarta: BPFE, 1989.

Sa'aduddin, Imam Abdul Mukmin. Meneladani Akhlak Nabi: Membangun Kepribadian Muslim, Bandung: PT. Remaja Rosdakarya, 2006.

Shihab, Dr. Quraish. Membumikan al-Qur'an, Cet. I; Bandung: Penerbit Mizan, 1992.

Shihab, M. Quraish. Tafsir al-Mishbah, Cet VI, Vol 14; Jakarta: Lentera Hati, 2006. 
Sudarsono, Etika Islam Tentang Kenakalan Remaja, Jakarta: Bina Aksara, 1989.

Saleh, Abdul Rachman. Pendidikan Agama dan Pembangunan Watak Bangsa, Jakarta: Raja Grafindo Persada, 2006.

Sanafiah Faisal, Metodologi Penelitian Sosial, Cet.I; Jakarta: Erlangga, 2001.

Sugiyono, Metode Penelitian Pendidikan; Pendekatan Kuantitatif, Kualitatif, dan $R \& D$, Cet. VI; Bandung; Alfabeta, 2008.

Sukardi, Dewa Ketut. Bimbingan Karir di Sekolah-Sekolah, Jakarta: Galia Indonesia, 1987.

Sunarto dan B. Agung Hartono, Perkembangan Peserta Didik. Jakarta: Rineka Cipta, 2002.

Suryobroto, B. Proses Belajar Mengajar di Sekolah, Jakarta: Rineka Cipta, 1997.

-------, Proses Belajar Mengajar di Sekolah; Wawasan Baru, Beberapa Metode Pendukung dan Beberapa Komponen Layanan Khusus, Cet. I; Jakarta: Rineka Cipta, 2002.

Sutisna, Oteng. Administrasi Pendidikan Dasar Teoritis untuk Praktik Profesional, Bandung: Angkasa, 1987.

Syahidin, Metode Pendidikan Qur'ani: Teori dan Aplikasi, Cet. I; Jakarta: CV Misaka Galiza.

Tjokrowinoto, Moelyarto. Beberapa Teknik di dalam Hubungan Kerja, Yogyakarta: Bulletin No.11, 1974.

Westra, Pariata. Human Relation, Yogyakarta: BPA UGM, 1977. 
80 | Sudiran /IQRO: Journal of Islamic Education Vol. 2, No.1, Juli 2019. 67-80

Halaman ini sengaja dikosongkan 